\title{
Clarice Lispector and Fernando Sabino in Letters Close to the Heart
}

\author{
Matildes Demetrio dos Santos \\ Fluminense Federal University, Rio de Janeiro, Brazil
}

\begin{abstract}
The point of departure for this essay is Cartas Perto do Coração (Letters Close to the Heart) of Clarice Lispector and Fernando Sabino. In this book, the interlocutors clarify the principles and the truths that govern their texts. In Clarice, the urgency to write, as a slow but potent force, highlights her artistic identity. For Sabino, who was practical in his professional choices, he usually submitted the content of his article to an editor or a publisher, although the dream of being a great novelist has seduced all his life. Therefore, in the field of this study, the letters changed between Clarice and Sabino extend their conception of a literary writing and show people how literature can contribute, continuously and dramatically, to the development of a personal expression.
\end{abstract}

Keywords: Clarice Lispector, Fernando Sabino, literary correspondence

\section{Introduction}

Literature is commonly supposed to be an act of faith and a justification of the human imaginative and creative capacity. These qualities are found in abundance in Clarice Lispector and Fernando Sabino's work: in their novels, in their tales, in their articles. And their private correspondence is not an exception. Letters Close to the Heart (2001) is different from anything of that sort, because it is essentially an act of generosity towards two young writers standing in the full field of art, possessed of a natural exuberance that has been only finding in the great artists.

In 2001, after Clarice's death, Fernando Sabino decided to get up his correspondence with Clarice, expressing very clearly his wistful longing for her. At the end of the Preface for the book of letters, he remembered the unexpected effect he had when he finished reading Clarice's first novel, Close to the Savage Heart: "I became bewildered". The book showed a strong sensibility going deep to the root of feelings. Later, when he was finally introduced to the author, he was completely captivated with her charm, strong personality, and bright intelligence.

The value of this correspondence is remarkable for it seems simple but it has certain complexities which invite exploration. The letters tell the readers something of how Clarice and Sabino have written certain books and reveal their ceaseless struggle to dominate language. Literature for them is a confrontation of the whole being with reality and the letters are an exercise to bring order to chaos, an effort by will, before creation. 


\section{The Act of Collecting and Saving}

Why do I go back to writing?

There's no need to ask such precise questions,

For, in truth, I have nothing to say to you;

However, your dear hands will receive this note.

-Goethe

Clarice Lispector and Fernando Sabino distinguished 20th-century Brazilian literature differently, each expressing themselves according to their own talent. Although over time, Lispector was the one who went deeper into the question of style and literary expression, both authors gained attention from the critics of the time and were hailed as promising young writers, destined to have a successful career.

At only 18 years, Fernando Sabino received a letter from Mário de Andrade dated January 10th, 1942, stating that after reading the short story "Os grilos não cantam mais" ("The grasshoppers don't sing anymore”), he was convinced that he was a promising artist and his writing had a future. Years later, in relation to that letter, Sabino said, "No encouragement can be greater for a newcomer in literature than those words of discerning understanding that could so precisely point out my qualities and excuse my flaws" (Sabino, 1982, p. 6). The young man pushed himself to serve literature, encouraged by the words of the most representative figure of national culture at the time.

Clarice Lispector's literary debut was equally significative. Her first novel, Perto do coração selvagem (Close to the Savage Heart), received the Graça Aranha Award in 1944. Antonio Cândido (1970, p. 131), in the article "In the Dawn of Clarice Lispector", noted "the atmosphere of greatness" that surrounded the novelist, who knew how to transform "words, which for many are not more than sounds or signals, into values". Persevering in her chosen path, the writer stayed faithful to her responsibility by working on her writing skills through her short stories, novels, essays, and articles.

Lispector and Sabino realized the effects of their triumphant debut in Brazilian literature when they established a connection through the letters, which were collected by Fernando Sabino in 2001, under the title Cartas perto do coração (Letters Close to the Heart). The interlocutors' narratives in this book clarify the principles and truths that governed their writing.

In Lispector, the strong impulse to write, as a potent force, highlights her artistic identity. She seemed to be above praise and ignored her own artistic value, regardless of how much she rigorously submitted herself to the search for semantic plurality. In a letter dated December 14th, 1956, when her manuscript for A maçã no escuro (The Apple in the Dark) was in the hands of Ênio Silveira, the editor from Civilização Brasileira, and the publisher J. Olympio, she expressed her suffering with their prolonged silence with respect to her work, which stemmed from a fear of the novel being a sales failure. Writing requires one to go beyond material concerns, and Lispector knew the precariousness of the process that brings a work to life. She insisted to Sabino that the editors' disregard made her feel "like a girl that makes a wedding dress and puts it away in a hope chest”. For her, this was akin to committing violence against the writer. She would prefer to self-publish than to see the originals forgotten in the editors' drawer, turning yellow with time (Lispector, Washington, December 14, 1956, p. 181). ${ }^{1}$

\footnotetext{
${ }^{1}$ To facilitate consultation of different editions, the name of the author's letters, the place and date of the letters will be cited in the body of the text.
} 
For Sabino, who was practical in his professional choices, the commercial purpose of a book was as important as its literary value. Having observed the editorial process firsthand, he knew that publishers' very profession forced them to close their eyes to the literary value of authors. In the case of Lispector, it was not a matter of negligence or lack of interest on the publishers' part; while Olympio was interested in her book, he knew that the publishing market was unpredictable and that it was important to wait for an opportune moment. As a consolatory gesture to Lispector, he enthusiastically alluded to the literature of Ênio Silveira, who had confessed to be "crushed under the impact of Clarice Lispector's literature", and he assured that "no book in Brazil and few foreign ones were of her stature” (Sabino, Rio, January 1957, p. 190). Each time he discussed with her the value of their writings, he had the sensation that the conversation was the same that they had already had a long time ago, and his benevolence did not satisfy her, but only served to project more shadows over her restless spirit. A completed novel was not a guarantee of pleasure for Lispector.

The writing profession brought Lispector and Sabino closer, but they did not comfortably share the same role. She had the tendency to begin the task of writing in restless moments that absorbed her entire being. For her, literature was movement towards an unknown and fascinating point, without knowledge of whether it could be reached, but nevertheless one to be undertaken anyway, in an incessant search for the creation of a new language.

In a letter dated from 1957, Lispector stated that she was extremely tired from the years-long effort of writing A maçã no escuro (The Apple in the Dark). From a distance, Sabino witnessed the entire process of creating the book, from the first notes written in 1951, during the six months which Lispector spent in Torquay, England. After, she continued writing in the United States from 1951 to 1956, until publication in 1961. During this time, she also wrote the short story collection Laços de família (Family Ties), published in 1960. After the book was ready, she suffered yet and found herself poorer but firmer and more secure within her expectations:

My book is one of my "truths", but I made a mistake, and for lack of courage within myself, I turned a "truth into just art”. I hid from myself as much as I could. I suffered with it and in it, but I didn’t come out free. I still feel very far from maturity, and I can’t even speak of “adolescence”; I can only say I stopped growing in childhood. (Lispector, Washington, Jan. 24, 1957, p. 193)

Sabino, taking things to the other extreme, wrote and published "remote control" texts, under advice from the patrons of the country's journalism industry. He was hired by the Diário de Noticias, Diário Carioca, and The Jornal in Rio de Janeiro, and his chronicles were circulated freely in the press. At the same time, he developed the works Ponto de partida (Starting Point) and Movimentos simulados (Simulated Movements), which he completed in 1956, when he condensed the two texts and published them under the title $O$ encontro marcado (The Appointment). He accepted with satisfaction, as befits a romantically happy writer, favorable reception from the public, but expressed certain disappointment at not having "had any interesting critiques come out yet” (Sabino, Rio, Jan. 1957, p. 189). Thanks to successful sales, the book was published abroad and adapted to the theater, a privilege reserved for famous writers.

The adulation, however, did not lead him to forget what he really wanted to do as an author. $O$ encontro (The Appointment) invited him to take another literary route that offered him some measure of freedom from being tormented by the idea that he was a writer for hire in a boat without a paddle for the daily press. The novel related to his past and seemed to equally refer to the future. He decided to send the book to his friend, as they were committed to helping each other when faced with dilemmas like the one above. In a letter dated 
January 8, 1957, Lispector wrote about the impact of the book made on her: "Your book surprised me”. This was the opening sentence of a very meticulous letter, hardly complacent and rich in criticism—particularly in pointing out the book's weaknesses:

The plot shows almost an absence of stratagem. It gives the impression that you didn't stop for an instant to find a "literary solution", that not once did you see yourself before an impasse, before asking a question such as "what do I do with this?” (Lispector, Washington, Jan. 8, 1957, p. 188)

She tried to discuss the gist of his literary work but the frankness of her attempts annoyed him. Despite her critical remarks it was her intention to prove that she was her friend, whether or not she liked the book. Being a voracious reader, Lispector absorbed everything the book had to offer. At the end, she finishes the long discussion with an intricate opinion: "I would actually have preferred it if you were not capable of writing it. But you were, and I am happy” (Washington, Jan. 8, 1957, p. 187). What was the intention of this statement?

As much as he reflected on it, Sabino could not find an answer to the enigmatic statement. He hoped to find the meaning, which would give him the certainty of having found his own diction for the fictional reality that was represented in his book. Nevertheless, Lispector's statement bothered him because it pricked at his certainty that he had acted correctly by writing the book; he believed he had come out of the novel better than he had been before he wrote it. In effect, $O$ encontro (The Meeting) was the achievement of two incompatible moments in his career as a writer, an abolished past and a present that he wanted to hold on to.

You can calculate what this book means to me; it is like "purgation”- evidently the motive for the extra literary order, but necessary so that I can feel that from now on that I am able to write about whatever I want. (Sabino, Rio, Jan. 1957, p. 189)

The situation was as follows: Sabino expressed himself the way he had either because he looked for and found coherence in his discourse or because doing so would open options for other flights of fancy that could satisfy him. Lispector, however, judged the novel as barely coherent, hurried in pacing, and inconsistent in plotting. Sabino disagreed with her, but then she was not asking for either validation of or opposition to her views. In reality, it neither was simply her way of persisting in things, despite the difficulties created by doing this. The two writers' correspondence did not stop. On the contrary, Lispector's comments became more incisive, urging him to step out of his shell and understand that her statement would have as another sense that he interpreted as negative:

I may have expressed myself badly when I said that I preferred that you were not a person capable of writing this book. Or perhaps, it is also possible, that I expressed myself more or less within the context. I don't know. What I wanted to say is that the book is painful, the book hurts, and I wanted you not to be the person that felt all you felt; I wanted for you to have been spared, I wanted for you to not be the person that crossed the dangerous street-even if you arrived safely on the other side. (Lispector, Washington, Jan. 24, 1957, Thursday, p. 192)

As if this was not enough, she continued to insist that he should not be afraid to affirm the discontinuous and the rupture, in order to propose a plural work, that he would find his destination or concealment in the demands of the writing. Unlike him, Lispector swore by the discontinuity of writing, preferring this ambiguity to realism with an autobiographical bias:

I don't know how to "give myself"; you know how to "give yourself”. (I know that I am being a total bore). And one of the mysteries of the art of writing is that sometimes we "give ourselves for others". I do not believe that it is "illogical” I thank you because if I "got something” I have to be grateful. (Lispector, Washington, Jan. 24, 1957, p. 194) 
The literary experiences of his friend always seemed fascinating to Sabino, because of the importance she placed on playing with language. He dropped their argument, but continued dreaming of being a great novelist. In a 1968 interview given to the Manchete magazine, in the section "Possible Dialogs with Clarice Lispector”, later reproduced in Letters Close to the Heart (Sabino, 2001, pp. 209-215), the issue resurfaced. In the article, he expresses his dream of being a great novelist and does not accept the limits he is subjected to: "supplying the newspaper or magazine that pays me with written material that corresponds to what they expect from me, that is, pleasing the reader” (p. 210). The dream of being a great writer seduced him, but his journalistic work had reduced him to a "piece" on the market. He failed to do what he hoped for. These disappointments overtook him, affecting his present and tormenting him with doubts about his literary abilities and his role as an artist in the literary and ideological scene in Brazil after the modernization of the 1920s and 1930s.

I have never felt like a writer, like a part of a generation. I have always felt alone, and this has perhaps been my mistake. I wanted to learn by myself and I lost my innocence. An artist is an innocent person. It was necessary to relearn to look at everything as if it were the first time. I looked at it as if it were the last. (Sabino, 2001, p. 213)

As can be observed in the letters, the battle raging inside Sabino aggravated his complex of being a "lesser author”, but it did not stop him from continuing in his routine as an editor and writer either, releasing texts that continued to interest readers because of their powerful plots. In 1979, with O grande mentecapto (The Great Halfwit), he went back to narrating the adventures of Geraldo Viramundo in Minas Gerais. In 1989, the book was adapted to cinema and directed by Oswaldo Caldeira. It was followed by O Menino no espelho (The Boy in the Mirror), a fictional autobiography. In 1991, he caused a controversy with Zélia, uma paixão (Zélia, a Passion), a biography that was authorized by Zélia Cardoso de Mello, Minister of Finance during Fernando Collor's term in office. The book reflected badly on the minister because of its chronicling of the scandals in his private life. He next published Aqui estamos todos nus (Here We Are All Nude) (1993) and, Com a graça de Deus (With the Grace of God) (1994), a humorous reading of the Gospel by Jesus Christ. This back-to-back literary output brought him enormous publicity, the craving for which his desire to be a superior artist had not suppressed.

The collection of letters exchanged with Clarice Lispector and Mário de Andrade shows that these friends tried to help Sabino to do his best in literature. In the letters, the image of a man in search of an artistic identity and tormented by his personal contradictions predominated. In 1981, he published Cartas a um jovem escritor (Letters to a Young Writer). In this correspondence, at the year of 1942, Fernando Sabino was just 19 years old and he had just finished writing his first novel. He was a young writer who wanted to be a success in life and literature at all costs. In the letter dated January 10, 1942, Mário de Andrade advised him to get away from the easy life and learn how to use his talent, giving all his leisure time to study, fond of literature. However, he came deaf to his master's advice: He married and went to New York, starting a new career as an international journalist. Some years later, he still had doubts about his future. With the publication of the novel A marca (The Mark) (1994), Sabino tried to determine what morals befitted an author who was in a paradoxical alliance of cynicism and sincerity. Uncertain, he hesitated about which path to take. Writing a letter, Mário de Andrade patiently dealt with him, betting on his talent: "Now it is you who is going to construct 'your sincerity' and your spontaneity. Until now, people chose you. Now you must make a choice for yourself” (Sabino, 1982, p. 142). 
Part of the teaching of Mário de Andrade did not really happen as seen in Letters Close to the Heart. Deep down, Sabino was a good writer who chased the dream of being a "brilliant" author, the writer of a masterpiece, celebrated for all critics in whole world. In the book, he is the editor, sender, and recipient of the correspondence that he kept with Lispector between 1946 and 1969. He made his friendship with the famous artist public, like an act of disinterested love, donation, and self-renunciation (Sabino, 2001, p. 213).

Despite the editor's simplicity, the book's organization is certainly not naive, making one think about what Gérard Genette, in the introduction of Paratextos editoriais (Editorial Paratexts) (2009) drew attention to by saying that a literary work rarely presents itself in a nude state. It demands attractive packaging that guarantees its good reception and consumption. Therefore, everything that accompanied a text and became a book, he referred to as paratext: The title, the author's name, the dedication, the preface, photos, and illustrations needed to follow a strategy that could guarantee a good reception from readers or critics. Would anyone have read Cartas perto do coração if the title did not have the names of Clarice Lispector and Fernando Sabino in the header accompanied by the subtitle "Two young writers united by the mystery of creation?" The back cover is white, the names and informative text are black, and the main title is red. In the right-hand corner of the page, there are two delicate sketches, made using a quill, of the faces of two friends sharing a silent intimacy.

It is a subtle way to allow for the organizer of the book, who also wrote the preface and dedication, to participate in its creation. Attached is a rare treasure: an interview with Lispector and Sabino. With regard to the notes, the organizer does not make much of an effort. They are few, reduced to the essentials, so as not to neutralize the immediate communicative value of the texts, which aim to awaken the complicity of readers through the sincerity of the feelings of a melancholic self, who strives to overcome the mutilating pain of separation:

We exchanged ideas about everything. We submitted our work to one another. Together, we reformulated our values and discovered the world, inebriated by youth. It was more than passion for literature, or for one another, unformulated, that united the two youths "close to the savage heart of life": what transpires in our letters is a type of pact between two people, solitary before the enigma that the future held for our destiny as writers. (Sabino, 2001, p. 8)

Therefore, the work announced itself as a precious chronicle of the irretrievable absence created by the death of Sabino's dear friend in 1977. The dedication, “Lately many years have passed”, immensely broadens the pain of a subject that is spiritually stripped and alienated by so many things. The phrase is by Rubem Braga, another of Sabino's great friends. In the body of a letter dated May 6, 1946, the phrase is repeated by the sad writer, who has grudgingly left Rio de Janeiro to work in a "New York Commercial Building, in a gigantic Fifth Avenue, that is awkward, ridiculous and aggressive” (Rio, May 6, 1946, pp. 12-13). As a future emigrant, Sabino experimented with the paradox of one who has yet to leave but already misses what is left behind. Years later, on March 30, 1955, the phrase came up again in the middle of a conversation a distressed Sabino had with Lispector, when he revealed that $O$ encontro marcado (The Appointment), the book to which he had dedicated his art and life, was "mercilessly limited as an artistic work" (Sabino, Rio, March 30, 1955, p. 125). At this time, Lispector, who was living overseas, was exceeding herself with each book.

Perhaps this is why As cartas perto do coração (Letters Close to the Heart) proposed a different type of approach by bringing a mishap encountered by one of the senders into the book. Sensitive and vulnerable to an extreme, Sabino did not hesitate to admit he needed others to live, and even to write, and in the space of the letters, he stubbornly and reverentially cited texts from known authors. There were verses by Olavo Bilac, 
Manuel Bandeira, and even his mentor Mário de Andrade, whose teachings he sought to pass on to Lispector. The work contained extraordinary explanations, confessions of plagiarism, and the desire to write like Virginia Wolf in Mrs. Dalloway. The authors cited, mixed in with the epistolary text, speak of his erudition and his emotional dependence.

From this comes the cruel paradoxical dedication, "Lately many years have passed": Sabino perceived a gift and power to dominate in Lispector that he did not have, and also perceived her struggle to give it to him knowing that he lacked it. With the publication of Cartas perto do coração (Letters Close to the Heart), Sabino associated his image with the powerful one of Lispector, and since this was private correspondence, the work brings the two writers involved in the same operation. The letter, as Michael Foucault (2006) has stated, is a way to "give yourself to see, to show your face along with the other" (p. 150). Thus, it was not very important that Lispector's critiques suffocated Sabino, because he deliberately offered himself to criticism.

\section{Traces of Daily Life and Literature}

I always wanted to "play high”, but it seems that I am learning that the high game is played in daily life, in which a person risks a lot more with much greater threats.

-Clarice Lispector

Supported in the fragmentation and vibration of daily living, Cartas perto do coração (Letters Close to the Heart) is a speech about the effort of doing good literature. Its brings the movement of life, thoughts, dreams, and fictions of the interlocutors that, despite writing rooted and delimited by the circle of the days, they disappeared behind a seductive voice, distinguishing the profile of the correspondence. Sending a letter is to live the pleasurable agony of waiting until the reply arrives. It was Clarice Lispector who began the correspondence, writing a long letter to Fernando Sabino and his wife, Helena, Paulo Mendes Campos and Otto Lara Resende, the best friends of Lispector who stayed in Rio de Janeiro. From her, they were a guarantee of friendship, a refuge from a lonely self who needs someone to talk:

This letter altogether seems like a speech-I would like to tell each one of you a little about the trip and it would be deceptive to not repeat facts or words.... Also, I am doing what I had agreed to do with Fernando on the other field: that he would write the first chapter.... It is a little of my wisdom. Really, I do not know exactly what to say. This face of mine that wore a happy expression at our good-bye shed tears on the plane. (Lispector, Bern, April 21, 1946, p. 9)

What metamorphosis is announced? Communication is common to all who look for contact. To have something to tell but not knowing what in particular does not inhibit the sender from speaking and does not lessen the desire to continue speaking. So what is the situation that, not being fictitious, provokes angst? The discomfort is caused by the move overseas. That year, Lispector moved to Bern in Switzerland, accompanying Amaury Gurgel, her diplomat husband. Her first impression of Bern was, "Well, you have to look at Bern through the window and close your mouth so as not to scream” (p. 9).

To be stuck in a space from which one cannot leave or even scream-do aesthetic feelings not arise there? Not being able to exempt herself from the move to Bern, the writer began to see it as an exile and, lifting herself from passiveness to action, compelled herself to explore the "beautiful and calm" city, complaining about the expensive life, observing the people on the street, feeling herself alone and unhappy.

Her autobiographical letter redesigned the way in which Clarice Lispector lived in exile. In Edward Said's reflections (2001, p. 46), exile is an incurable fracture between one's self and their true home and the sadness 
that is caused by the separation that can never be overcome. And the incomplete and prompt letter, written in fragments, captures traces of the mood of the author, who describes her situation while she writes to others who observe and analyze her. In Lispector's multiple and varied dialogues, she superimposes exciting images of herself and her literary affairs. She talks about her daily life and refers to her passionate and obsessive habit of readings from afternoon to night. When Sabino asked her in a letter dated June 10, 1946, what she did at three in the afternoon, she replied playfully that perhaps he was a ghost for having guessed that, at that time, she was the most demanding woman in the world: "Sometimes I am reduced to the essential, that is to say, only my heart beats. When it passes, six in the afternoon comes, also indescribable, in which I am blind” (Bern, June 19, 1946, Wednesday, p. 20). Sharply, she discovers the failure of this activity. In the stories from Laços de família (Family Ties), the feeling of nausea manifests itself in the afternoon, at the threshold of Ana and Laura, the protagonists of “Amor" (Love) and "Imitação da rosa” (Imitation of the Rose), two middleclass housewives living a domestic life labyrinth.

Clarice Lispector makes use of the instability of the epistolary form to make the letters a simulacrum of her personal life, a place to capture facts and annotate feelings in the process, whether commonplace or suggestive, in a style that is always original and refined. Upon reading the note from Álvaro Lins saying that her two novels, Perto do coração selvagem (Close to the Savage Heart) and The Lustre (The Chandelier) were "mutilated and incomplete", she photographed herself and sent the picture to her friend with the comment: "With the exhaustion of Paris, in the middle of the crates, femininely and sick, I cried from discouragement and weariness". She continued to write, enjoying the pleasure of communicating in a dialect that was particular to her as a woman and writer who was simultaneously a housewife and an artist: "I finally arranged a maid that in one day gave order to disorder — she was a true woman. A great woman, without a doubt, named Rosa, an Italian, God bless her”. There are eternal monologues, in the rhythm of one who has nothing to say but needs a friend to talk to: “Today I spent the day reading; at three o'clock, I read your letter and Helena's note again (Bern, June 19, 1946, Wednesday, p. 21).

With Fernando Sabino, she kept a spontaneous and natural relationship, as if he were everywhere, bringing him up insistently in her speech, in the fragility of someone who needs another so as not to completely immerse oneself in fiction, in the "abstract that interests me ever more" (June 19, 1946, p. 20). One letter states, "I got to know Frau Hulda Pulfer. She is the concierge here and does the cooking, cleans up the house, and does the laundry" (Bern, July 27, 1946, p. 36). The author of these letters fluctuates between reality and fantasy and it was in the day-to-day routine, among known people, that she ran the risk of losing her balance and being absorbed by the search for the unknown.

At home, the imaginary novelist occupied herself with the women who used to clean her house. She looked at them as if she wanted to surprise the secret identity of each one of them: Hulda Pulfer; Martha Baumann; Anna Michalek, a Polish woman; and an American nurse, "the softest, beautiful, fattest and largest" women she met by chance (Washington, February 22, 1953, Sunday, p. 94).

In a letter from Bern dated July 27, 1946, she said that upon meeting Frau Hulda Pulfer, she was dazzled by her luck: "I dreamed of her and almost followed her around the apartment so as not to lose sight of her" (p. 37). For her, imagination was a creating force and she insistently followed the woman with her eyes, in the possibility of beating the clock, as if everything were brief and definitive in the field of invention. For the recipient of her letters, she liked to describe precisely the little incidents from her life, personalizing each one as they had occurred at the moment of writing. There are moments in which she uses direct dialog, in French or in 
English, which she did not translate so as "not to ruin" the reality. Such a strategy comes from literature itself. In one scene, she is surprised by Hulda Pulfer, who was mortified to see the owner of the house occupied with an activity that was reserved for her. Various situations that are equally rich in interpretation appear in the polymorphic body of the letters:

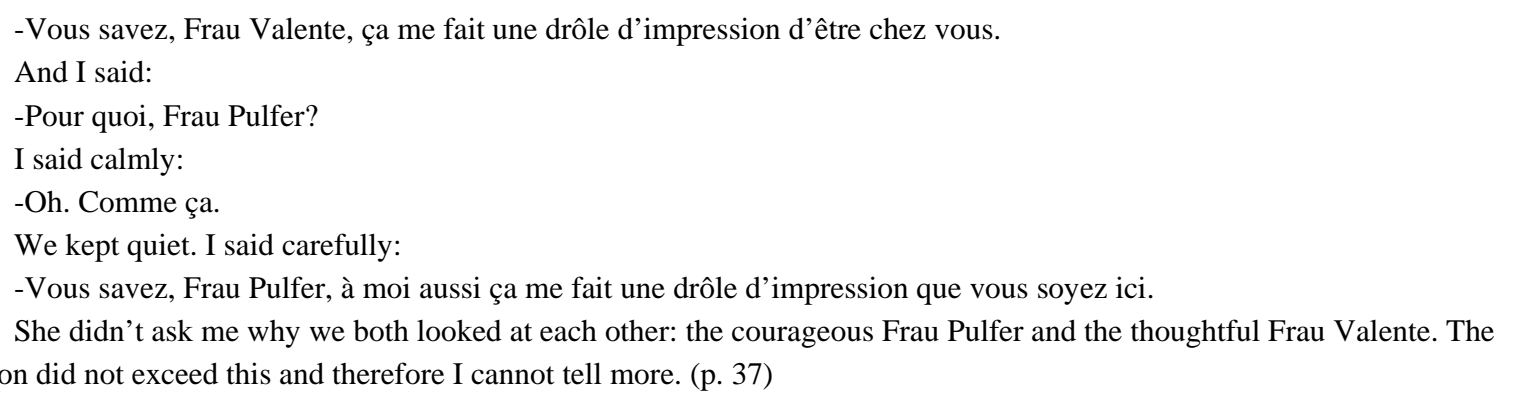

Thus, along with the mundane activities of daily life, with references to dates and actual events, the letters contain sketches of narratives, with few lines, all unfinished and "loose", and referring to events narrated in previous letters. A significant example is in the letter from Bern, dated August 14, 1946, which refers to a work Lispector began and abandoned: "It was about a girl that, because she was short in spirit and very slow, she really forced this weak spirit and this movement gave her a type of sanity” (p. 53). This fragment is the first reference to Macabéa, the protagonist of A hora da estrela (The Time of the Star), its last novel made known to the public in 1977.

Fragments like these appear in the letters like anonymous trails, sometimes clouded, from the texts that the novelist intended to write. However, nothing is very clear since Clarice Lispector side-steps and prefers to search, as if she were not worried about the results. In this way, she denies the temptation to continue about a "possible" Macabéa and admits that the task is very difficult: "I see that I did not say anything that it is none of that, and I see that I am quite lost. I do not want to speak any more; all of this is horrible and heavy" (Bern, August 14, 1946, p. 53).

According to Roland Barthes (1988), it is possible to affirm that Clarice Lispector uses elements of her own experience to make a record of herself in the text of the letters like a character of a novel. In the letter from July 27, 1946, she looked at the question from all sides:

This intimate life comes to the point of having no external signs ends up by taking away my direction and sense of things. It seems to me that I have reached a point from which I can no longer escape. (Lispector, pp. 35-36)

Feeling privileged to be part of this relationship, Sabino united his voice with that of Lispector, offering himself as a safe harbor, in a firm decision to support the creative agitation of his friend. He also knew how to take advantage of such dialog by creating fictions about himself while he was still in the United States. Upon his return to Rio de Janeiro, his rhetoric became more limited, without great leaps of humor, a result of working for a major publisher and press.

While in New York, however, there was a lot of chatter in his letters and a lot of inner monologue. There, a great part of his life was occupied with filling in the disorienting emptiness of living overseas, living a lonely and unhappy life. The new reality was artificial, and it was akin to living in a nightmare. He refused to belong to that place, and that translated into an intransigence that made him sick: "I have gone daily to the dentist" is a phrase that he repeats to the point of it becoming unbearable. 
The content of the letter from New York dilates itself substantially and transforms into a rosary of complaints and confessions of all types. The sentences are short or long and they all start with the past participle. A monologue of lamentations occupies the entire text, with the sender being crushed by the cruel reality: "I have had many headaches, and I have heard many scary stories". His life was disorderly and he could not impose an order on his chaotic way of living: "I have had many nightmares. Yesterday, I dreamed of a rat jammed in the wall, whimpering in pain” (New York, June 10, 1946, p. 17).

Sabino self-reflected, wasting a lot of time expressing his misfortunes for what he could have or should have done. He loved literature, but he felt gulled by the editorial market, totally divorced of his own dreams. On the other hand, Clarice recognized her necessity and was totally engaged in the strength of her realization.

\section{Conclusion}

A correspondence is in a sense necessarily limited to the moment and it is also a magical fusion between life and art, but its implication is profound, for it can become a point of entrance to a writer's work. Letters Close to the Heart escapes time and prophesies the future, because the two authors felt ahead of the time with their revolutionary dissatisfaction with everything about them. Clarice is a mystery to herself and to the world. She wrote to save her soul like Virginia Woolf or Kafka. She was able to throw her life away to save her own literature. On the other side, acting as editor or a professional of letters contracted to write for a magazine and a newspaper, Fernando Sabino accepted his proposed usages. This work gave him respectful and intellectual admiration, but not his masterpiece. Certainly, the light of literature felt on him, but he was dependent upon the editorial market and many times the "holy fire" came when the situation required. In his letters he recognized that his dear friend had been touched by a divine stroke and was able to pull off her warm coat to dance lonely in the rain.

\section{References}

Barthes, R. (1988). O rumor da língua (The rumor of language) (M. Laranjeira, Trans.). São Paulo: Brasiliense.

Becker, C. (2013). O discurso da escolta: as notas e seus problemas (o exemplo de Zola) (The speech's escort: The notes and his problems the example of Zola). Patrimônio de memória, 9(1), 144-156.

Blanchot, M. (2005). O livro por vir (The future book) (L. Perrone-Moisés, Trans.). São Paulo: Martins Fontes.

Cândido, A. (1970). No raiar the Clarice Lispector (In the dawn of Clarice Lispector). In Vários escritos (Several writings). São Paulo: Duas Cidades.

Foucault, M. (2006). O que é um autor? (What's an author?) (6th ed.). Lisboa: Nova Veja.

Genette, G. (2009). Paratextos editoriais (Editorial paratexts) (Á. Faleiros, Trans.). São Paulo: Ateliê Editorial.

Goethe. (n.d.). Werther. Rio de Janeiro: Editora Tecnoprint.

Sabino, F. (1982). Cartas a um jovem/De Mário de Andrade a Fernando Sabino (Letters to a young writer/From Mário de Andrade to Fernando Sabino) (2nd ed.). Rio de Janeiro: Record.

Sabino, F. (org.). (2001). Cartas perto do coração (Letters close to the heart) (3rd ed.). Rio de Janeiro/São Paulo: Record.

Said, E. W. (2001). Reflexões sobre o exílio e outros ensaios (Reflexions on exile and other essays) (P. M. Soares, Trans.). Sao Paulo: Companhia das Letras. 